\title{
List of contributors - Biography Statements
}

\begin{abstract}
Jo Appleby
Jo Appleby is an Associate Professor in Archaeology at the University of Leicester in England. She has been interested in archaeological approaches to human ageing since studying for her $\mathrm{PhD}$ (2008), which investigated the relationship between ageing, the body and social roles in the Austrian Early Bronze Age. She has published a number of papers on this subject since then. Her other research interests include the investigation of mortuary practices (especially cremation) and the British and European Bronze Ages.
\end{abstract}

\section{Jo Buckberry}

Jo Buckberry is a Reader in Biological Anthropology at the University of Bradford in England. She completed her $\mathrm{PhD}$, on later Anglo-Saxon funerary archaeology and osteology, at the University of Sheffield in 2004. She researches Anglo-Saxon funerary archaeology from a bioarchaeological perspective, osteology, palaeopathology, and evidence of violence-related trauma. Her research into age estimation, which started with her Masters dissertation on auricular surface age estimation, has sparked an interest in understanding longevity and age identity in the past.

\section{Christine Cave}

Christine Cave is based at the Australian National University where she has recently completed $\mathrm{PhD}$ research on the topic of 'Living with One Foot in the Grave: The Elderly in Early Anglo-Saxon England'. She was Australian Student Representative for the Australasian Society of Human Biology (2012-16). Her interests include age, sex and gender identity, mortuary archaeology and Early Anglo-Saxons, with a side interest in Philippine archaeology.

\section{Sean Denham}

Sean Denham is an Associate Professor and osteoarchaeologist at the Museum of Archaeology, University of Stavanger, Norway. He received his BA from Tufts University, Massachusetts, United States, and both his MSc and PhD from Queen's University Belfast, Northern Ireland. He has conducted numerous studies of both human and animal remains from all periods, with special emphasis on burnt/cremated remains. His zooarchaeological research interests focus on Mesolithic diet, while in the realm of human osteology he strays towards health and mortality in Medieval Norway. Currently he is a post-doctoral fellow attached to The Research Council of Norway funded research project 'Medieval Urban Health - From Individual to Public Responsibility, AD 1000-1600'. He is a member of the Norwegian National Committee for Research Ethics on Human Remains.

\section{Colm Donnelly}

Colm Donnelly is the Director of the Centre for Archaeological Fieldwork in the School of Natural and Built Environment, Queen's University Belfast, Northern Ireland. His research focuses on the history, architecture and archaeology of Late Medieval and early seventeenth century-Ireland. $\mathrm{He}$ is also involved in the development of community archaeology in Northern Ireland. He is a co-editor of The Science of a Lost Medieval Gaelic Graveyard - The Ballyhanna Research Project (2015) and co-author of The Glens of Antrim in Medieval Times (2018).

\section{Chrysanthi Gallou}

Chrysanthi Gallou is Assistant Professor in Aegean Archaeology and Director of the Centre for Spartan and Peloponnesian Studies at the University of Nottingham in England. She studied Archaeology and History of Art at the National and Kapodistrian University of Athens and then completed MA and PhD studies at the University of Nottingham under the supervisor of Professor William Cavanagh. She has written widely on Aegean Archaeology, the archaeology of Mycenaean children and childhood, and the archaeology of Laconia, including monographs entitled The Mycenaean Cult of the Dead (2005) and The Mycenaean Burial Tradition in Lakonia (2018).

\section{Mari Høgestøl}

Mari Høgestøl heads the Collections Department at the Museum of Archaeology, University of Stavanger, 
Norway. She has mainly worked on the management of cultural heritage and collections, and has also directed several archaeological projects. She was educated at the University of Oslo, and her research interests focus on social archaeology, burial rituals, age and gender, as well as rock art studies and agro-pastoralism.

\section{Mélie Le Roy}

Mélie Le Roy currently holds a post-doc position at Aix Marseille University (LAMPEA, LabexMed). She completed her doctorate in biological anthropology at Bordeaux University. Her research concerned the study of skeletal remains of children and the social consideration of this part of the population through funerary practices, based in GIS in the analysis of funerary settlements. Her recent publications include Le Roy et al. 2016 "Distinct ancestries for similar funerary practices? A GIS analysis that compares funerary with biological and aDNA data from the Middle Neolithic necropolis Gurgy "Les Noisats" (Yonne, France)" published in the Journal of Archaeological Science. She also co-edited a monograph Children, Death and Burial: Archaeological Discourses which assembles a panorama of studies with a focus on juvenile burials.

\section{Grete Lillehammer}

Grete Lillehammer is Emerita Professor and archaeologist at the Museum of Archaeology, University of Stavanger, Norway. She is a Vice-President and one of the founders of the Society for the Study of Childhood in the Past (SSCIP), and a member of the Editorial Board of the international journal Childhood in the Past. She was educated at the University of Oslo (BA) and the University of Bergen (MA, PhD), and was Visiting Scholar at the Department of Archaeology, University of Cambridge, England, in 1997. Her research focuses on social archaeology, in particular children and childhood studies, and gender and burial ritual studies, but also includes cultural heritage, landscape, and museum archaeology. She organised the 2008 SSCIP international conference and edited the monograph Socialisation, Recent Research on Childhood and Children in the Past (2010), and has published extensively on the archaeology of childhood.

\section{Nina Maaranen}

Nina Maaranen is a postgraduate researcher at Bournemouth University in England. She received her MSc in Human Osteology and Palaeopathology at the University of Bradford and her Master of Arts degree in Archaeology at the University of Helsinki. Her interest in human remains was sparked while working for the Finnish Workmen's Huts in the Theban Mountains project in Luxor, and since then she has participated in several excavations in both Finland and the Near East. Her current focus is on biodistance analysis under the Hyksos Enigma project.

\section{Eileen Murphy}

Eileen Murphy is Professor of Archaeology in the School of Natural and Built Environment, Queen's University Belfast, Northern Ireland. Her research focuses particularly on human skeletal populations recovered from prehistoric Russia and all periods in Ireland. She is particularly interested in the use of approaches from bioarchaeology and funerary archaeology to help further understanding of the lives and experiences of people in the past. She has published widely and is the co-editor of Children, Death and Burial: Archaeological Discourses (2017) and the editor of the international journal, Childhood in the Past.

\section{Marc Oxenham}

Marc Oxenham is Professor of Bioarchaeology in the School of Archaeology and Anthropology, The Australian National University, Canberra. He was President of the Australasian Society of Human Biology (2012-14), an Australian Future Fellow (2013-17), elected a Fellow of the Society of Antiquaries of London in 2011 and elected a Fellow of the Australian Academy of the Humanities in 2016. Over the past two decades he has undertaken archaeological and/or bioanthropological research in Japan, China, Cambodia, Thailand, Vietnam, Indonesia and the Philippines. His research specialisations include the reconstruction of health from human skeletal and dental remains, mortuary archaeology (including that of Anglo-Saxon Britain), and human identification and estimation of the time since death in forensic anthropological contexts.

\section{Katharina Rebay-Salisbury}

Katharina Rebay-Salisbury is a prehistoric archaeologist with a research focus on the European Bronze and Iron Ages. Her interests include prehistoric (gender) identities and cultural interpretations of the human body as expressed in burial practices and art. After gaining her PhD at the University of Vienna, Austria, in 2005, she was a post-doctoral researcher at the Universities of Cambridge and Leicester. Her recent monograph The Human Body in Early Iron Age Cen- 
tral Europe was published with Routledge in 2016. She returned to Vienna in 2015 and currently directs the ERC-Starting grant project 'The Value of Mothers to Society: Responses to Motherhood and Child Rearing Practices in Prehistoric Europe', which investigates the relationship between women's reproductive and social status. In 2017, she gained the venia legendi to teach at the University of Vienna.

\section{Stéphane Rottier}

Stéphane Rottier is a bioanthropologist and archaeologist at the UMR PACEA of Bordeaux University in France. His research focuses on funerary practices in European prehistory and on methods and theory for archaeothanatology. He completed his $\mathrm{PhD}$ research on Late Bronze Age funerary archaeology in 2003 at Bourgogne University. He has been a lecturer in Bordeaux University since 2007 where he has developed courses on archaeothanatology and field teaching and supervised numerous postgraduate projects in these areas.

\section{Frédéric Santos}

Frédéric Santos is a technician in statistics at the laboratory UMR PACEA of Bordeaux University in France. His main work focuses on improving or developing methods relating to age-at-death assessment and sex determination in the fields of biological anthropology and archaeology, as well as the statistical treatment of missing data.

\section{Anne-marie Tillier}

Anne-marie Tillier, an Emerita CNRS Research Director at the University of Bordeaux in France, is a biologi- cal anthropologist and specialist in growth studies of past populations. Her initial research involved studying the Palaeolithic children from the site of Qafzeh in southwestern Asia which she then expanded to encompass other time periods, establishing an innovative approach to the archaeological record in Bordeaux. Her personal research into the dynamics of Eurasia's populations has been carried out from a twofold perspective, biological and cultural, and has focused on co-evolutionary processes among Palaeolithic huntergatherers (Neanderthals and early modern humans) and evidence of funerary behaviour. This research has included fieldwork in the Mediterranean Levant undertaken as part of an international pluridisciplinary team working at the Qafzeh, Kebara and Hayonim sites.

\section{Guðný Zoëga}

Guðný Zoëga has an MSc in Forensic Anthropology from Bradford University, England, and a PhD in archaeology from the University of Oslo. She is the Head of the Archaeological Department of the Skagafjörður Heritage Museum in northern Iceland. She has researched extensively on Icelandic Viking-Age and Medieval sites, with a special focus on settlement history and early Christian cemeteries and cemetery populations. She has a special interest in how funerary data, osteology and archaeology can be used to reconstruct household patterns, demography and everyday living conditions of Viking-Age and Medieval Iceland. Her most recent project is the Skagafjörður Church and Settlement Survey, an interdisciplinary project funded by the National Science Foundation that has been examining the relationship between early settlements and church history. 